\title{
The Opportunities and Challenges in Innovative Thinking Development of the New Era Public
}

\section{Management}

\author{
Jiang Ke* \\ School of Public Finance and Management \\ Yunnan University of Finance and Economics \\ Kunming, P.R. China \\ 1341824069@qq.com
}

\begin{abstract}
Public management is for the public. It aims to pursuit public interests and concerns a wide range of complex public activities of the state, governments, and other public organizations. Management innovative thinking is a way of thinking through which public management propels social progress in the period of economic and social transition and perfects management mechanism of governmental organizations. This paper conducts in-depth research and analysis of opportunities and challenges in the development of innovative thinking in public management, and proposes pertinent strategies adapting to the development trend in the era of knowledge-based economy better, thus promotes the development of cultural and institutional management of public administration.
\end{abstract}

Keywords-public management, innovative thinking, development opportunity, challenge

Public management has always been one of the topics that academic scholars and the public are paying close attention to. In practice, public management theories and concepts have also been extended. The quality of public management depends on the implementation of specific measures and relevant policies. The formation of these management policies and measures is based on the concept of public management and innovative thinking. Innovative thinking is a macro concept. It is an idea or ability that the society needs at any time. These thoughts will eventually be practiced and developed step by step. Only when thinking is practiced can we prove our thinking. The right value and its implementation are not only important driving forces for development, but also important sources for social progress. [1]

Innovative thinking in public management is a new leap of management thinking, which mainly includes innovations in concepts, knowledge, and issues. It is the most important and fundamental to promote implementations of management innovation, through which innovative thinking comes true. The transformation of behavior, for which innovative thinking is treated as an important foundation, is actually the fundamental driving force for the development of all human civilization.

In the new era, the role of officials is more complex and their responsibilities are more important. Thus, officials must have a broad vision and become open minded. They must also have the ability for innovate thinking. Public management concerns the interests of the majority. It is a public activity that can serve the public and that pursues the public interest. Due to the diversification of public interests, public management has the characteristics of innovation, and management innovation depends on the innovation of thinking.

\section{THE BASIC ELEMENTS AND BASIC CHARACTERISTICS}

\section{OF MANAGEMENT INNOVATIVE THINKING}

Innovative thinking is a high-level form of human thinking and a crystallization of human wisdom. The broad sense of innovative thinking refers to all forms of thinking activities that play a role in the process of innovation; the narrow sense of innovative thinking refers specifically to the thinking activities that bring forth innovative ideas. The application of innovative thinking in management has its own characteristics, and management innovation can be understood from its basic constituent elements and characteristics.

\section{A. Elements of Management Innovative Thinking}

The constituent elements of management innovative thinking mainly include concepts, knowledge and issues.

First, concept refers to people's views or understanding of objective things, sometimes refers to the specific perceptions, representations or impressions, formed by the human senses as a result of external objective things. It also refers to the social consciousness reflected as social existence, which includes the concept of people's understanding of various social phenomena, the formation of ideas, and the theoretical image of social ideology, and so on. [2]

Second, knowledge refers to human experience and achievements that have been summed up through continuous conquest of nature and social practices in the developmental process. It is indeed the human spiritual and cultural wealth and achievements. [3] Only when people constantly expand their knowledge to optimize their own knowledge structure system can they strengthen their own management innovative thinking and improve their ability to solve various problems, so that they can face various difficulties.

Third, the issues refer to the contradiction or distance between the known and the unknown, the existent and the in existent in the process of human thinking and understanding. Management innovative thinking activities usually focus on 
management issues. The main purpose is to solve management problems. In the whole process of thinking activities, this contains the inherently essential thinking problem of the contradictions between subjective understanding and objective matters, and the thinking task proposed for solving this contradiction is its thinking existence form. [4]

\section{B. Basic Features of Management Innovative Thinking}

Management innovative thinking relies on and reflects the actual management activities. It is a dynamic and complex process. It has its own specific developmental characteristics, which are negativity, self-denial, independence and transcendence.

First, the negativity of management innovative thinking means to think about management from the positive side or the negative side, to put the management thinking model out of backwardness, timeless, and worthless, and to make it progressive, advanced, and valuable. On the one hand, management innovative thinking negates existing management practices, and on the other hand, it negates ideas that reflect past or existing management behaviors. The negation of the former depends to some extent on the existence of the latter. No matter how the theory or the concept is, at the beginning it cannot be developed in a group form. Meanwhile, it also requires that the individual's innovative developmental plan and innovative cultural thinking fully meet the actual law of progress and development of management activities, so as to meet the actual reality of management activities. Needs can be further recognized and accepted by the public to further serve social management activities.

Second, management innovative thinking in a certain sense reflects the independence of the main body of innovative thinking. From the perspective of the main body of management innovative thinking, it includes two aspects: individual innovative thinking and group innovation thinking. These two are interdependent and promote each other. In the aspect of independence, some outdated and backward problems need to be promptly clarified and eliminated in a timely manner by adding more content that possesses practical development significance and value. The concept of modern management innovation plays an important role in guiding and supporting the overall progress and development. Only by highlighting the important role and importance of independence can it be accepted by the public and serve the management activities.

Thirdly, denationalization is one of the most important features of management innovative thinking. The management development and innovative thinking will further evolve and develop into a traditional sense of management philosophy and management consciousness. What is demonstrated in this process is also the process of scientific management. Traditional concept and management awareness on the company have profoundly demonstrated the overall progress and development of past management innovative thinking, reflecting the progress of the overall management thinking. This process also belongs to the dialectical view of management philosophy and developmental thinking in a high degree of consciousness of the traditional management concept, which embodies the overall process of management innovation. [5]

Fourth, transcendence is the most prominent features of management innovation thinking. The transcendence of management innovative thinking is based on the understanding of the objective laws of management development. The transcendence of management innovative thinking should conform to the objective law of management, and only through this way, can we surpass it. Transcendence should be embodied in a deep grasp of the law of management or a profound understanding of the laws of management science. Paying our full attention to the transcendence of management innovation thinking is of great significance to the development and progress of public administration. [6]

\section{OPPORTUNITIES FOR THE DEVELOPMENT OF}

\section{INNOVATIVE THINKING IN PUBLIC MANAGEMENT}

In the new period of development of public innovative thinking, it provides more opportunities for the development of innovative thinking in public management, but the opportunity is fleeting. Therefore, the grasp of opportunity affects the public management in a new era. As the main body of public management innovative thinking, public managers must not only seize the opportunities for personal development, but also pursue organizational development opportunities. Therefore, the grasp of opportunities has a certain degree of particularity, and the ideal of development is related to the officials expectations for possible environments. Among them, under the background of globalization, the comprehensive reform of governmental governing mechanisms has provided new ideas for public officials. It has, to a certain extent, promoted the leap in the quality of innovation in public management and provided new opportunities for the development of public management.

\section{A. Scientific management can be achieved.}

Public management is a general term for the management of public affairs. The specific content involves administrative management, educational management, and other aspects. It is necessary to ensure scientific decision-making in order to achieve the demanded goals as soon as possible. The decision-making stage is very critical to the management process and the final result. It requires officials to analyze and negotiate in advance based on relevant data, combine the current situation, estimate the direction of future development, and consider various risks and make decisions. In the past, public management relied heavily on experience and lacked analysis of scientific data. Now that information technology is developed, society has entered the era of big data, and cloud computing capabilities have rapidly increased. It can not only analyze the status by integrating historical data, but also interact with the masses in time through the network and accept feedback from the masses, thus making decisions more scientific [7].

\section{B. The quality of service has more improvement room.}

From the modern management concept, if public management wants to achieve good results, it should transform old ideas and establish a sense of service so that management can gradually move closer to the service sector and continuously improve the quality of services to meet more new needs of the public. The essential characteristic of management is its poly trope, which are inextricably linked to information. With the advancement of information technology, public management services are increasingly diversified. Not only are the contents rich and varied, but 
also the entire environment is more open. It lays the foundation for high standards and high-quality management services. Let's take government management as an example; the traditional government management model gives people the impression of being an order issuer. Today, government management promotes transparency, attaches importance to the participation and supervision of the people, and the quality of public services continues to increase. Under the new circumstances, the individual characteristics of public demand become more obvious. The development of innovative thinking is conducive to keeping up with the trend of the times, adjusting strategies in a timely manner, and meeting the increasing diversity of individual needs of the public.

\section{Social risks have been reduced.}

As an important part of social management, public management is affected by various inside or outside factors. In practice, it will inevitably lead to risks and hinder management activities. For example, financial crisis, terrorist attacks, in addition to the market, man-made risks, including natural disasters, the degree of harm can be imagined. Taking natural disasters as an example, in the past, disaster rescue has its backwardness in terms of methods and technical equipment, and the success rate is relatively low. Innovative thinking not only originate from experience, but also takes into consideration the application of various modern technologies to propose new methods and increase the success rate. The same is true in the financial crisis. The global economy has been closely linked. China must dare to innovate, actively change its economic model, and follow the principles of the market economy in order to conform to the development of the times and promote the improvement of its ability to manage social risks.

All in all, the opportunity for the development of public management is to create better conditions for public management, but at the same time it also raises some new requirements for public managers. It requires public officials to have several features: First, they should own high degree of sensitivity to grasping opportunities; second, there is a strong desire for grasping opportunities; and third, there is a high degree of confidence that can accurately seize opportunities to promote the overall growth of individuals and organizations. At present, China's public management tends to be diversified in the development of innovative thinking. The government is constantly transforming the concept of traditional public administration, emphasizing the continuous change of public management innovative thinking, and adopting a "people-oriented" approach to institutionalize the market economy that meets the needs of the public. . At the same time, it also emphasizes the highly integrated multi-elements and hopes to expand the public administration work with the reform process of the national government's public administration. This will ultimately meet the basic development objectives of the country's harmonious society and will pave the way for the construction of a service-oriented government and a service-oriented management platform.

\section{CHALLENGES IN THE DEVELOPMENT OF}

\section{INNOVATIVE THINKING IN PUBLIC MANAGEMENT}

Affected by the current social system in this country, the development of public management innovative thinking is also facing multiple challenges. Its development is not flat detailed and detailed analysis, and the development of public management innovative thinking needs to deal with issues from the following aspects.

\section{A. Public Management Needs to Emphasize New Service}

\section{Ways in Work Innovation}

The public management emphasizes the idea of a new service approach in the process of work innovation. This innovation change is also based on the innovation of management thinking. However, due to the long-standing state of traditional public management thinking, it may be difficult to meet the reality of the current development of the new social situation. Demand, so the government must seek to break away from the government service model in the process of public management thinking innovation. The openness of government information can increase public understanding of the government's effective platforms and channels, assist the government to collect social public information in a rational and efficient manner, meet the realistic development needs of a harmonious society, then continuously promote the image of the government, while improve government efficiency. The purpose is to fully meet the new challenges of public management in the context of urbanization. [8]

\section{B. Government must face up to the public service function,}

\section{manage innovation, innovate, and distinguish new}

\section{challenges}

The government must not only face up to the challenges in public service innovation, but also new challenges in the positioning of thinking, which emphasizes the new orientation of governmental functioning. Still, they must face up to the generalization and weakening of the contents of governmental functioning, work through both the creative thinking and development of public management by taking a government-based approach. The international economic and technical cooperation with generalized functions strengthens the line, fully protects the legitimate rights of citizens and enterprises in society, and actively provides all-round and meaningful public services for the whole society. In addition, in the course of the management and innovative thinking of public service functioning, it is also necessary to realize the organic transmission of public service content to understand the government and the grassroots people to a certain extent, and to continuously strengthen the government's ability to collect and process information so as to provide better quality for society.

\section{Rationally respond to the challenges of economic}

\section{globalization}

Officials must rationally respond to the challenges of the development of the global economy, actively learn from foreign innovations in modern public management, learn from the use of reference, change the current relatively simple domestic public management model, and guide the public from many aspects such as politics and law, economics, finance, and social livelihood. The contents of management work should be comprehensively applied, reasonably prepared, and the implementation of the strategic 
plan should be emphasized at all times to promote the healthy development of the government's public sector and to make market and government more compatible. In addition, it is necessary to comprehensively build and improve the public management mechanism, and always ensure that public management has a certain role in promoting the development of modern society.

\section{MEASURES TO RESPOND TO Challenges IN THE}

\section{Development of InNOVATIVE ThINKING IN PUBLIC}

\section{MANAGEMENT IN THE NEW ERA}

In order to further promote the development of innovative thinking in public management, we must make it innovative and comprehensive, and even predictable and diverse. In the context of globalization, it also provided great impetus for national public management model reform. In China, at this stage, public administration issues and the severe challenges of globalization have laid the foundation for the development of innovative thinking in public management.

\section{A. The government should effectively change the traditional}

\section{concept of public administration to promote the}

\section{innovation of public management thinking}

In the context of globalization, it induces new requirements for government management. In the management concept, it should be society, task, result and customer oriented. The above guidance needs to regard customer needs as an important basis for the development of the government's public secto and as the main objective to be followed in the process of government reform. It also needs to highlights the service-oriented characteristics of management [10].

\section{B. Reconstruct the management innovation thinking of}

\section{government functions in light of the objective reality of}

\section{the development of the times}

At present, the innovation and transformation of China's government functions has become an inevitable trend. The expansion of the functioning scope has also become a necessary condition for the government's service-oriented management practices. In this regard, the Chinese government should comprehensively increase the emphasis of innovative thinking in public management, commit to promoting China's overall national strength, continue to deepen development in the field of international economics, technology, and maximize the protection of the vital interests of our citizens. By introducing basic rights and legal rights in other countries, it ensures the improvement in our public service quality.

\section{The New Service Paradigm Thought of Innovative Public}

\section{Management}

The innovative construction of the government's public management service needs innovation based on management thinking. For a long time, the government's public management thinking has always remained at the traditional level, and it has been difficult to meet the practical needs of the new situation in social development. In this regard, it is believed that the innovation of management thinking should advance with the social development, break away from the shackles of the traditional government service model, implement online services with application of digital tools, promote the development of public services toward information, and expands the scope of public affairs services. Through this way, the traditional "big government" image can be transformed to a new organizational form based on the Internet and achieve innovation in the management system. The core of this new public management service lies in replacing the traditional public service model with the application of the network. Through publicizing the government affairs, the government provides more channels for citizens to understand the government, and at the same time it helps the government to collect social public information more efficiently. In this way, it will better meet the development needs in the perspective of a harmonious society, integrate the people's opinions, and promote the promotion of the government's image. At the same time, it will further promote the efficiency of the government's work, and ultimately it will directly affect the construction of the city's image.

\section{Fully absorb and learn from domestic and foreign}

outstanding management experience to promote the

innovation of our country's public management thinking

\section{and practice}

The global integration development has directly drawn the distances of various countries in the world, and has provided more in-depth and convenient conditions for exchanges among countries. In order to be able to follow the international trend to better adapt to the real needs of the development of globalization, the development of officials' innovative thinking in China should fully draw lessons from the public management concepts and models of advanced government with advanced experience, break the shackles of the traditional thinking concept, and gather politics. Economy, law and management are all integrated management. Specifically, it should involve the improvement of the fairness of social management, the strengthening of internal organization planning and strategic management quality, and the overall improvement of customer service quality. From the macro perspective, the public administration of government targets on the public, but the public also determines the effectiveness of the government's public management to a large extent. Since then, the market and the government have always been independent, and in the new situation, it is necessary for them to fully coordinate with each other, so as to effectively promote the innovation of China's social public management system. [9]

\section{CONCLUSION}

Countries in the world are in an international environment of economic globalization and integration. China's public management system is undergoing severe impacts of market rules and the new situation. The development of innovative thinking in public management faces unprecedented opportunities and challenges. We must 
uphold the principle of seeking truth from facts, learn from the wisdom of all human beings, grasp the opportunities given to us in the new era, create new public management with Chinese characteristics, and push China's current public management reforms to an active and effective development direction. The innovation of public management is indispensable, and the overall innovation of our country's public management, including concept innovation, system innovation, culture innovation, etc., is to form a continuous innovation mechanism through the integration of these innovations. The realization of all these ideas depends on the innovation of officials' management thinking. The establishment of a new modern public management system is a precondition for the development of the times, as well as an institutional guarantee for the comprehensive construction of a well-to-do society and the realization of socialist modernization. The innovation of China's public management system must have an international vision and localized thinking and actions. Based on the experience of the public management of developed countries and the country's national conditions, socialist democratic politics can be established. The development of a market economy and the requirements of the continuous progress of Chinese society need a new public management system with Chinese characteristics.

\section{REFERENCES:}

[1] Hou Jing. Opportunities and challenges in the development of innovative thinking in public management [J]. Times Finance. 2017, (08): 265.270.(in Chinese)

[2] Zhao Di. Analysis of opportunities and challenges in the development of innovative thinking in public management [J]. Southern Entrepreneurs. 2018, (01) 24.(in Chinese)

[3] Zhu Yuzhi. The environment, opportunities and directions for the development of innovative thinking in public management [J]. Modern Business. 2007,11(18):208-209.(in Chinese)

[4] Lu Han. Opportunities and challenges in the development of innovative thinking in public management[J]. Journal of Anhui Technical College of Water Resources and Hydroelectric Power, 2016, 16(4): 90-93.(in Chinese)

[5] Zhou Yongxin. Analysis of opportunities and challenges in the development of innovative thinking in public management [J]. Farm Staff. 2017, (11): 298.(in Chinese)

[6] ZHANG Xiaohong, FEI Baosheng, FANG Hai, The challenge of public management in the era of big data and the exploration of its innovation model[J]. Journal of Anhui University of Science and Technology, 2016, 18(5): 11-15.(in Chinese)

[7] Ma Xiaojuan, Analysis of the Opportunities and Challenges in the Development of Innovative Thinking in Public Management [J]. Human Resources Development, 2017, (10): 33-34.(in Chinese) 